\title{
Articles
}

\section{Progressive Eras, Periods of Reaction, and Constitutional Change}

\author{
By Danny Nicol
}

\begin{abstract}
This article argues that "political herding" plays a crucial role in driving and shaping constitutional change. It links the prevalence of political herding to a psychological phenomenon, "social influence." It goes on to argue that constitutional change is often driven by the desire for certain substantive policies, which in turn are determined by whether, in a particular epoch, the political community is herding in a progressive or reactionary direction. Contending that the general phenomenon whereby political communities go through recurrent swings to the left or to the right has been neglected by scholars, this essay aims to give this phenomenon the centrality it merits in relation to the evolution of the British constitution. Accordingly it considers the 1906 Liberal government, the 1945 Labour government and the lengthy succession of post-1979 neoliberal governments, analyzing how substantive progressive and reactionary programs led to constitutional change. Finally this article considers the legitimacy both of political herding itself, and of political herding's impact on constitutional change.
\end{abstract}

\section{A. Introduction}

Human beings are herd animals. Their compulsion towards group action has been readily apparent in the world of finance and investment, but applies no less to politics, including constitutional politics. That the herding instinct is common to financiers and politicians alike has been well illustrated by the recent economic crisis. The first phase of the crisis can readily be attributed to the group conduct of the financial elite and the second phase to the collective behavior of the political elite. The original credit crunch of 2008 was, by all accounts, largely the result of the calamitous herding in favor of sub-prime mortgages as a form of investment. ${ }^{1}$ The second phase-the Eurozone crisis-was in large measure caused by the adoption, years earlier, of the Euro by the governments of poorer European Union Member States heedless of the relative weaknesses of their national economies. A

\footnotetext{
* Danny Nicol is Professor of Public Law, University of Westminster.

${ }^{1}$ See Alex Brummer, The Crunch: How Greed and Incompetence Sparked the Credit Crisis (2009).
} 
collective compulsion by political leaders in favor of European integration blotted out any more guarded assessment of the consequences of losing the right to devalue on the more fragile economies. ${ }^{2}$ These two illustrations of group behavior, being somewhat reminiscent of the fate of the Gadarene swine, scarcely give a favorable portrayal of collective action. Often, however, the consequences of herding are not so incontestably unfortunate. Nonetheless the examples from the economic crisis usefully serve to convey the immense power of the herding instinct in humans, in both financial and political spheres.

This contribution is devoted to political herding. It argues that political herding plays a seminal role in driving and determining constitutional change. This argument is offered as an antidote to the academic tendency towards "constitutional reform with the politics left out." ${ }^{3}$ This article contends that constitutional reform is not objective or supra-political. It is no technocratic science. Rather, it is driven primarily by the desire to achieve or maintain certain substantive policies. The quest for these policies is in turn determined by whichever ideological tendency, progressive or reactionary, holds sway in a given epoch. Thus the dominant political mood of the time-the question of whether we are living through a progressive era or a period of reaction-often determines the nature of constitutional development. ${ }^{4}$ While there is extensive scholarship on particular periods in which political opinion has swung to the left or right, the general phenomenon whereby political communities go through these recurrent swings is curiously neglected. This article aims to give this phenomenon the centrality it merits. We can see that historically, progressive eras and periods of reaction have been central to the development of the British political system, and to the evolution of the British constitution.

The extent to which scholars should seek to link political events to recurring human traits remains controversial. ${ }^{5}$ Be that as it may, it is difficult to avoid the sense of recurrence in the accounts of the two progressive eras and one protracted period of reaction in recent British political history offered here. ${ }^{6}$ The first progressive era to be examined is the 1906 Liberal government, which introduced the rudimentary framework of the British welfare state. The second is the 1945 Labour government, which deepened and strengthened the

\footnotetext{
${ }^{2}$ The transnational dimension of herding is not the focus of this essay. On this aspect, see DANNY NICOL, THE Constitutional Protection of Capitalism (2010). See also ian Bartle, Globalization and eU Policy-making: The NEOLIBERAL TRANSFormation OF TELECOMMUNICATIONS AND ELECTRICITY (2005).

${ }^{3}$ See Anthony Wright, The Constitution, in PARTY IDEOLogy IN BRITAIN 191 (Leonard Tivey \& Anthony Wright eds., 1989).

${ }^{4}$ It is not part of my argument that constitutional change is always so driven.

${ }^{5}$ See J.E.S. HAYWARD, The Political Science of Muddling Through: a de facto Paradigm?, in The Polttical SCIENCE OF BRITISH POLITICS 3 (J.E.S. Hayward \&Philip Norton eds., 1986).

${ }^{6}$ See Philip Norton \& J.E.S. Hayward, Retrospective Reflections, in The Political SCIENCE Of British Politics (J.E.S. Hayward \& Philip Norton eds., 1986).
} 
welfare state, introduced the National Health Service and nationalized key industries. The third era to be analyzed is the period of reaction which commenced in the late 1970s, which widened the gap between the rich and the poor and brought about extensive privatization. In all three cases it becomes clear that the era's constitutional changes or constitutional conservatism stemmed largely from the desire to promote substantive policies. These policies were themselves the product of the dominant ideology of the age.

\section{B. The Pattern and Psychology of Political Herding}

It will be observed that the progressive eras and the period of reaction considered in this essay follow a common pattern. An influential section of the political elite, located within a party, becomes discontent with the political, social and economic status quo. That group then fashions a new ideology, and engages in a struggle to establish it as the philosophy of the epoch. To this end it enlists intellectual support to argue that its new "common sense" best accords with notions of human freedom. The ideological tendency assumes hegemony within the party. With the party in office, a period of radical policy change takes place that alters the nature of capitalism. The drive to achieve policy change in turn dictates the nature of constitutional change. Finally, the new hegemony attains such domination that the opposition party transforms itself, to accommodate the prevailing ideology. Thus the new "common sense" becomes for a period, the dominant way of perceiving and understanding the world. ${ }^{7}$

While political herding is an activity engaged in by the elite, it may nonetheless reflect dissatisfaction on the part of the general public with the status quo. Attempts to move British politics decisively to the left or right are unlikely to succeed unless they have wider resonance. Furthermore a progressive era or period of reaction requires public approval. The role of the electorate is to express support or disapproval for change by favoring the party of change over the party of the status quo at general elections. In some cases the decisive election may bring the party to office. In other cases, where the progressive era or period of reaction gathered pace during a government's lifetime, the choice can be seen as sustaining a sitting government. Hypothetically it is possible that the decisive election may come only after the opposition party has changed its position and adopted the major policy stances of the governing party, in which case public approval would be compromised. Tellingly, however, this was not the case in any of the three periods examined here. This would seem to indicate that the opposition party tends to change its stance partly in deference to its perception of the public mood. After the politicallydecisive election the electorate may get scant opportunity to revisit the political shift since the parties may converge towards the new consensus. An additional problem is that there may be asymmetries in the electorate's approval at the politically-decisive election, for instance political change might not secure the approval of all four parts of the United

${ }^{7}$ Antonio Gramscl, Selections from the Prison Notebook 322 (1971). 
Kingdom as a multi-nation state. The significance of any such failure is likely to vary over time according to the extent to which voters view the political entity as Britain or as one of its constituent parts.

In any event a progressive era or a period of reaction can be seen as a great social movement, but where does the individual fall within this construct? In recent times, social psychologists have increasingly concluded that part of the self is malleable, and molded by life experiences. ${ }^{8}$ The desires of individuals, including their political aspirations, are substantially affected by the real and imagined pressures of others. Psychologists call this phenomenon "social influence." Individuals may conform to dominant group opinion as the best way to make a correct judgment (informational influence) or in order to avoid the consequences of appearing deviant (normative influence). Such dominant group opinions may alter not merely the behavior of individuals, but also their very perceptions. ${ }^{9}$

According to the work of Serge Muscovici, this emphasis on the social context of thoughtthe way in which society provides the basis of thinking-means that one cannot perceive the individual as an isolated Robinson Crusoe, yanked out of his historical context. By the same token neither can one regard the individual as the blinded bearer of a received ideological tradition. Rather, ideology and prevailing common sense contain contrary themes that provide the context for individual and collective dilemmas. ${ }^{10}$ Ideology cannot, therefore, avoid producing dilemmas. For this reason individuals do not always accept handed-down illusions. By the same token, society cannot be left outside the door of the psychology laboratory. ${ }^{11}$ Thinking is an inherently social process because even where it consists of a form of dialogue within the individual-as is frequently the case-the content of that dialogue has historical and ideological roots. The concepts involved in that dialogue, and the meanings attributed to those concepts, are constructed historically and ideologically through social dialogue and debate. ${ }^{12}$ Thus the social creation of mental states forms an essential part of a progressive era and of a period of reaction. It is against this backdrop that political and constitutional change takes place. ${ }^{13}$

\footnotetext{
${ }^{8}$ Saul Kassin, Steven Fein \& Helen Rose Markus, Social Psychology 95 (7th ed. 2008).

${ }^{9}$ See id. at $252-59$.

${ }^{10}$ See, e.g., Serge Moscovici, The Invention of Society: Psychological EXplanations for Social Phenomena (1993).

${ }^{11}$ Michael Billig, IDEology AND Options 11 (1991).

${ }^{12}$ Michael Billig, Susan Condor, Derek Edwards, Mike Gane, David Middleton \& Alan Radley, Ideological Dilemmas (1988). The authors accept that one can differentiate between lived ideology-the culture of a society-and intellectual ideology-the very different concept of an intellectual system of ideas. Nonetheless there are contrary themes both between and within lived and intellectual ideologies.

${ }^{13}$ A pioneering attempt to link psychology to constitutional matters is made in Dawn Oliver, Psychological Constitutionalism, 69 CAMBRIDGE L.J. 639 (2010).
} 
Before we tackle our three eras, it may be worth considering the appropriate conception of constitutional change to deploy in this analysis, given that the United Kingdom is a country without a codified constitution. I have adopted a wide conception of the idea of the constitutional. For the purposes of this article, the constitutional is defined as embracing all reforms that bring about durable, though not necessarily permanent, change to the British system of government. This interpretation is generous enough to embrace alterations in economic governance and even changes to the internal rules of the political parties. I have favored this wide conception because of the absence of compelling reasons to retreat to more orthodox and narrower conceptions of the constitutional.

\section{The Liberal Government 1906}

Let us now consider our three historical periods. What do they tell us about the relationship between constitutional change and general political shifts to the left or right? We start with the progressive era ushered in by the Liberal government of 1906. The Liberal Party won the 1906 election by 377 seats to the Conservatives' 157, but this landslide did not immediately herald an epoch of social reform. Rather, the Liberals became more radical while in office. An emerging progressive wing of the Liberal Party dubbed the New Liberals was present in the House of Commons. These MPs discarded the Gladstonian belief in limited government and self-reliance, believing in a greater role of the state in protecting the weak. ${ }^{14}$ They included rising ministers David Lloyd George, Winston Churchill, and C.F.G. Masterman.

In addition to its parliamentary following, New Liberalism attracted an intellectual base. The new ideology was born out of grave social problems highlighted by two major surveys-Charles Booth's study of London and Seebohm Rowntree's survey of York. ${ }^{15}$ These surveys revealed the extent and severity of British poverty. They in turn inspired a normative literature. Oxford philosopher T.H Green urged a more positive use of state intervention to correct the deficiencies of the broadly-good but imperfect capitalist system; L.T. Hobhouse advised collective action for mutual advantage; and J. Hobson, New Liberalism's foremost propagandist, promoted a greater State role. ${ }^{16}$ A group of New Liberal writers also gravitated around a Liberal periodical, The Nation, including J.L. Hammond and Henry Brailsford. ${ }^{17}$ Sir Herbert Samuel MP, in his classic book Liberalism, argued that against the backdrop of intolerable social conditions, an enhanced state role would enlarge rather than diminish the freedom which Liberals held dear. Lloyd George

\footnotetext{
${ }^{14}$ DUNCAN WATTS, WHIGS, RADICALS AND LIBERALS 1815-1914 137-38 (2002).

${ }^{15}$ Chris COOK, A SHORT HISTORY OF THE LIBERAL PARTY 1900-84 47 (1984).

${ }^{16}$ See Oliver, supra note 13 , at 139.

${ }^{17}$ See WATTS, supra note 14 , at 47.
} 
argued that British Liberalism promoted freedom better than continental Liberalism by improving the living conditions of the multitude. These writings confirm that New Liberals sought not to replace capitalism but rather to reduce poverty in order to make capitalism more productive. The theory was that capitalism was not working to full capacity. This was because the distribution of wealth was so uneven that it deprived the masses of the ability to buy goods, leading to chronic under-consumption. Poverty was also making the British workforce less competitive with that of Germany, whose workers were mentally and physically fitter than the British. At the same time, the adoption of a more egalitarian politics by the Liberals would help counter their nascent rival, the Labour Party. Thus, progressive policies could be reconciled with an acceptance of capitalist economics. The system of private ownership could be made to work for the benefit of a larger section of society through what Churchill dubbed "a slice of Bismarckianism."

The progressive era began in earnest in 1908 when Sir Henry Campbell-Bannerman resigned as Prime Minister, due to his poor health, and was replaced by Herbert Asquith. Although Asquith never felt at home with radicalism, he assented to the new departures put forward by Lloyd George and other ministers, and New Liberalism made tremendous strides. ${ }^{18}$ By 1910 the government had established old age pensions, wage boards, labor exchanges, and had extended governmental control to natural resources and town planning. But social improvements had, of course, to be paid for. The Liberals introduced changes to the taxation system, whereby the percentage of government income derived from direct taxation rose from forty-four percent to sixty percent. Furthermore the Liberals introduced a steeper gradation of income tax, and introduced a differentiation between earned and unearned income. ${ }^{19}$

It was precisely the desire to implement this progressive economic and fiscal policy which led to the constitutional crisis over the powers of the House of Lords. Their Lordships' notorious rejection of the "Peoples' Budget" of 1909 was not entirely unexpected because the Upper House had a track record of frustrating Liberal governments over issues such as Irish home rule and the extension of the franchise. But the Lords' antipathy towards the Liberals had increased in the wake of the 1906 landslide. Their Lordships had, for instance, rejected or severely amended government proposals on education and licensing. The clash with the Lords over the Budget would, however, come to dwarf these earlier disagreements.

The government required an additional $f 16$ million in revenue in order to meet the growing costs of its program. Lloyd George as Chancellor of the Exchequer portrayed his proposals as "a war budget" to tackle "poverty and squalidness." His proposals involved raising income tax, with a super tax for incomes over $£ 5000$ and a land tax. Their Lordships

\footnotetext{
${ }^{18} / d$. at 48.

${ }^{19}$ G.R. Searle, The Liberal Party: TRIUmph And Disintegration 1886-1929 97 (1992).
} 
were particularly enraged by the prospect of a twenty percent revenue tax on unearned increments in land values and a capital tax on the value of undeveloped land and minerals. This was seen as an onslaught on property rights. The land tax proved particularly controversial since it necessitated a survey of land ownership which their Lordships feared would provide propaganda for those who opposed the inequalities in wealth and property ownership. ${ }^{20}$ Peers had not rejected a Finance Bill for some 250 years, yet they did so in 1909 by 350 votes to 75, prompting an immediate response from MPs in the form of a resolution declaring that the Lords' action was "a breach of the constitution and a usurpation of the rights of the Commons." It took two general elections in 1910 before the Lords passed the Parliament Bill which reduced their power from veto to two-year delay. They did so in 1911 by a seventeen-vote majority, under the threat of George $V$ creating sufficient Liberal peers to pass the measure if the existing Lords resisted. Against this backdrop the Conservatives and House of Lords did not seriously contest the Liberals' most important measure of the period-the National Insurance Act 1911-that provided State insurance against illness and unemployment, despite the fact that the legislation provoked much outcry throughout the country. ${ }^{21}$

It deserves to be emphasized that the Parliament Act was not inspired by the pursuit of some abstract principle. Rather, constitutional change was driven by the imperative need to enact what was perceived as a crucial economic measure which formed a seminal part of the New Liberal program. This is not to deny that the 1911 reform had general impact, or that it could be justified on grounds of democratic principle. As Watts observes, the Parliament Act meant that a government with a clear majority and early in its life, could get its program through Parliament and onto the statute book-something we now take for granted, but which at the time represented a momentous democratic step forward for the country. ${ }^{22}$ This is worth noting, because of more recent criticisms of the type of majoritarian democracy which the Parliament Act has engendered. It is enlightening to consider contemporary attacks on parliamentary sovereignty against the backdrop of the Liberal Party's reform. Professor Paul Craig, for instance, has criticized parliamentary sovereignty on the grounds that its present manifestation can no longer be supported by the normative arguments for the doctrine put forward by classic authors such as Blackstone and Dicey. Blackstone, Craig argues, supported parliamentary sovereignty because it provided a "balanced constitution" in which Lords and King checked the power of the Commons. Craig notes that today's constitution is very different:

The current position, in which the executive is formed from the governing party and controls the House of

\footnotetext{
${ }^{20}$ See Oliver, supra note 13 , at 148 .

${ }^{21}$ See WATTS, supra note 14 , at 55.

${ }^{22}$ See Oliver, supra note 13 , at 156.
} 
Commons, and in which the counterweights to the House of Commons power (in terms of the House of Lords and the King) have fallen away, is very far from the ideal of the balanced constitution described by Blackstone. $^{23}$

It is not obvious why we should defer too much to classical authors of earlier centuries; the continued existence of parliamentary sovereignty can easily be justified on more contemporary grounds. ${ }^{24}$ But in any event it is far from clear that Blackstone's "balance" was aimed at protecting or enhancing the basic liberties of the multitude. A more politicized account might draw attention to Blackstone's non-judicial role as Tory MP for a rotten borough. Blackstone did not concoct his constitutional doctrines in a politically neutral vacuum. Is it not more likely that-like the House of Lords in the Parliament Act crisis-balance was desired in order the safeguard the wealth of the rich against egalitarian demands? On this reading the balanced constitution merely served to enable the representatives of the well-to-do to veto the equality-gains of the have-nots. We should be wary, therefore, of assuming that balance is necessarily desirable. ${ }^{25} \mathrm{~A}$ more contextual analysis is furnished by Searle who observes that the constitutional crisis had raised issues of fundamental importance for ordinary working people because it was very much in the interests of the labor force that Radicalism should prevail. The labor movement had a vested interest, therefore, in securing a reduction in the powers of the House of Lords. ${ }^{26}$

If successful, a progressive era or period of reaction prompts the Opposition to shift its political ground. This was certainly the case with regard to the 1906 Liberal reforms. While there may have been periods in which state benefits were reduced, notably the Geddes Axe of the early 1920s when the coalition of Conservatives and Lloyd George Liberals markedly reduced public spending, nonetheless the early welfare state proved enduring irrespective of which party held office. Nor was there any move to reverse the demotion of the House of Lords. Searle argues that far from Liberalism becoming discredited, most Liberal beliefs and values became so widely accepted that there seemed no need for a separate party to campaign on their behalf. By the 1920s it could almost be claimed that "we are all Liberals now" since Conservatives and Labour alike drew heavily on Liberal

\footnotetext{
${ }^{23}$ Paul Craig, Sovereignty of the United Kingdom Parliament after Factortame, 11 Y.B. EUR.L. 221, 237 (1991).

${ }^{24}$ See e.g.,DAnny Nicol, The Constitutional Protection of CAPITAlism ch. 1 (2010) (describing the conception of democracy).

25 "Balance," like "the rule of law," is a word/phrase which has a force or power of its own. For a constitution to lack balance automatically casts it in an unfavourable light. But, as Paul Craig himself has observed, one has to be clear as to the conception of balance which is being posited, and the particular theory of justice on which that conception is based. See Paul Craig, Formal and Substantive Conceptions of the Rule of Law: An Analytical Framework, PuB.L. 467, 487 (1997).

${ }^{26}$ See WATTS, supra note 14 , at 96.
} 
thinking and policy. Bentley has observed that by the 1920s "everyone believed in Liberalism but no-one would actually vote for it." ${ }^{27}$ Sir Ernest Barker, a political philosopher, noted how the Liberals had transformed attitudes in favor of a greater governmental role: "While in 1864 orthodoxy meant distrust of the State, and heresy took the form of a belief in paternalistic government, in 1914 orthodoxy means belief in the State, and heresy takes the form of mild excursions into anarchy. ${ }^{28}$ This consensus could convincingly be regarded as not just a policy but as a constitutional consensus, involving as it does the question of the legitimate ambit of State activity.

\section{The Labour Government 1945}

We now go forward in time to our second progressive era, the Labour government of 1945-1951. This government had its ideological origins in the slump of the 1930s. Faced with a severe economic slowdown, the political elite were moving in favor of economic activism even outside Labour's ranks. Thus Harold Macmillan, who wrote The Middle Way in 1938, advocated a mixed economy and planning and was militating in favor of a new center party with a large Labour contingent, while Lloyd George was presenting the government with proposals for a British version of Roosevelt's New Deal. ${ }^{29}$ Within the Labour Party, however, the move towards state intervention was particularly marked, borne out of the perceived failure of the second Labour government to bring about economic revival. As with the 1906 progressive era, so too the 1945 Labour landslide was the legacy of a powerful intellectual trend-the revival of British socialism in the late $1930 \mathrm{~s}^{30} \mathrm{~A}$ new leadership was emerging that wished to pursue a clear democratic socialist path distinct from the "Lib-Labism," which had characterized Ramsey MacDonald's premiership and Philip Snowdon's chancellorship. The party leader Clement Attlee, writing in 1937, discerned a "spirit of a new era" in which "the dominant issue of the twentieth century is socialism." To this end he sought to dissociate Labour from MacDonald's "philosophy of gradualness" which he regarded as "almost indistinguishable from Conservativism. ${ }^{31}$ An intellectual head of steam was generated by disappointment with MacDonaldism and the 1930s slump, and a succession of publications appeared arguing for a more radical Labour program. To this end Hugh Dalton wrote Practical Socialism (1935), Douglas Jay penned The Socialist Case (1937), and Evan Durbin published Case for Democratic Socialism (1940). These volumes countered not only MacDonaldism but also criticized "the flood of quasi-Marxist volumes pouring forth in the 1930 s... proclaiming

\footnotetext{
${ }^{27}$ M. BENTLEY, The Liberal Response to Socialism 1918-29, in ESSAYS IN ANTI-LABOUR HISTORY (K.D. Brown ed., 1974).

${ }^{28}$ ERNEST BARKER, ESSAYS ON GOVERNMENT 124 (1914).

${ }^{29}$ Ben Pimlott, Labour AND the Left in the 1930s 145-47 (1977).

${ }^{30}$ KenNeth Morgan, The Labour Party Since 1945, in UK PolitiCAL PARTIES SINCE 1945 (Anthony Seldon ed., 1990).

${ }^{31}$ Clement Attlee, The Labour Party in Perspective (1937).
} 
the imminent collapse of capitalism." ${ }^{32}$ These authors promoted a vision of "socialism focused on state management of a still largely capitalist economy where a public sector dominated." ${ }^{33}$ Once again, they linked economic and social policy to ideas of human freedom. Durbin, for instance, believed that economic freedom was not possible in an economy based on the profit motive, and that a central planning authority was necessary. Dalton likewise sought a Supreme Economic Authority, responsible to the Cabinet, to plan the fight against poverty, insecurity and unemployment. ${ }^{34}$ Labour's trend towardscomparative-radicalism culminated in the party's publication in 1937 of Labour's Immediate Programme, which specified policies for a five-year term: Planning through a national investment board; nationalization of the Bank of England, coal, power and transport; a 40-hour working week; paid holidays; and the improvement of health services.

For Labour, the Second World War presented an invaluable opportunity to show the viability of, if not necessity for, the Party's policies. ${ }^{35}$ Labour ministers were effectively coordinating the home front on behalf of the wartime coalition. ${ }^{36}$ Moreover "total war" required the implementation of Labour's collectivism and a shelving of the Conservative culture of free enterprise. ${ }^{37}$ In this regard a new policy document, Labour's Home Policy (1940), was in effect providing the ideological framework for later war programs. The coalition's creation of millions of jobs effectively discredited the 1930s-acceptance that governments could not create employment. By emphasizing state intervention, planning and controls in order to win the war, Labour made it clear that it viewed the wartime coalition's measures - which amounted to a sort of proto-nationalization in terms of State control of mines, railways and other basic industries-as part of a permanent process. By contrast, the Conservatives saw these measures as a temporary expedient, since they opposed nationalization as resolutely as Labour advocated it. ${ }^{38}$

An even starker division in the wartime coalition emerged on health and the welfare state. The publication of the Beveridge Report in 1942, and the refusal of the government to implement it straight away, prompted the only occasion on which Labour forced a division of the Commons on a policy issue, allowing the Party to coalesce around a concrete issue. The rebellion gave Labour the opportunity to carve out a distinctive health policy, a

\footnotetext{
32 Douglas Jay, Change AND Fortune 63 (1980).

${ }^{33}$ Ben Pimlott, Hugh Dalton 223 (1985).

${ }^{34}$ Geoffrey Foote, The Labour Party's Political Thought: A History 183-99 (1985).

${ }^{35}$ ANDREW THORPE, A HISTORY OF THE BRITISH LABOUR PARTY 98 (1987).

${ }^{36}$ Id. at 99-101.

${ }^{37}$ Robert Pearce, AttleE's LAbour Governments 1945-51 14 (1994).

${ }^{38}$ See THORPE, supra note 35, at 108.
} 
National Health Service free at the point of need, whereas the Conservatives retreated to less comprehensive proposals. When the general election was called in 1945, voters perceived Labour as more likely to avoid the mistakes of the inter-war years and to introduce the social legislation which a more radical electorate was prepared to entertain. By contrast the Conservative campaign, which reflected Hayek's new thesis that economic planning, would lead to tyranny, ${ }^{39}$ failed to capture the public mood. ${ }^{40}$

Once in office, Labour implemented the main planks of its program within three years, and did so with remarkable unity of purpose. The manifesto policies generated no divisions within the party until the issue of steel nationalization arose towards the end of Labour's time in office. ${ }^{41}$ Nationalization of basic industries was implemented rapidly, but Labour's program was far from being based on "the dictatorship of the proletariat;" rather, the rationale for public ownership was efficiency-industries would be taken over if they failed to satisfy the criteria of national service. It was therefore ailing industries, such as coal, gas and electricity, which were taken over, and arguably the government failed to use nationalization as a more far-reaching weapon of change. As for welfare reforms, the government swiftly brought in the National Insurance Act 1946 whereby workers received pensions, sickness benefit, unemployment benefit and funeral benefit in return for a national insurance contribution, and the National Assistance Act 1948, which gave financial help for those with no other source of income. ${ }^{42}$ The framework of the National Health Service-while drawing on the Beveridge proposals-was distinct from the original plans and more socialistic, being non-contributory, financed mainly from general taxation and involving the nationalization of the hospitals. ${ }^{43}$

Opinion is divided as to how to assess Labour's reforms. Miliband characterizes Labour in 1945 as mere managers of State capitalism, the party's sole purpose being to make capitalism more efficient. ${ }^{44} \mathrm{~A}$ more favorable evaluation is offered by Morgan, who characterizes the period as the "first partial advance of the dynamic of democratization in our political processes." ${ }^{45}$ Irrespective of which of these assessments one finds the more compelling, the period can nonetheless surely be seen as one of progressive social reform which arguably forged a consensus which endured until the late 1970 s.

\footnotetext{
${ }^{39}$ Friedrich. A. HAYek, The RoAd to Serfdom (1986).

${ }^{40}$ Keith Laybourne, The Rise of Labour 105 (1988).

${ }^{41}$ KINGSLEY MARTIN, HAROLD LASKI (1953).

${ }^{42}$ See THORPE, supra note 35, at 123.

${ }^{43}$ See PEARCE, supra note 37 , at 48.

${ }^{44}$ RalPh Miliband, Parliamentary Socialism 288 (1972).

${ }^{45}$ KenNeth MoRgan, LABOUR IN POWER 1945-1951 (1984).
} 
On one reading, the Labour government was predominantly conservative when it came to constitutional matters. To be sure, both Labour and the Conservatives were loyal to the specifically Westminster model of parliamentarianism. Therefore Labour made only minor changes to the constitution as traditionally conceived. ${ }^{46}$ Attlee, in his book The Labour Party in Perspective back in 1937, emphasized the need to face down the House of Lords in the likely event that it would try to frustrate Labour's policies by using its delaying power. He stressed that a Labour government could not afford to wait in impotence while its measures were held up. The will of the people, as expressed at the polls, had to prevail. ${ }^{47}$ Yet, in the event, Labour was in no hurry to reform the Upper House. This was for the simple reason that the bulk of Labour's program met no serious resistance from their Lordships. Indeed it was only towards the end of Labour's term, when the Party was having difficulty with its legislation to take over the steel industry, that the government introduced legislation to curb the Lords. The immediate inspiration for the Parliament Bill 1949, which reduced their Lordships' power of delay from two years to one, was as a preemptive measure to get the Steel Bill through. ${ }^{48}$ Again, constitutional change was a means to a substantive policy end. Aside from the Parliament Act of 1949, Labour eschewed radical change to the British system of government. This can also be explained by the link with the implementation of substantive policy. The example of reform of the civil service provides a good example. Before 1945, socialists had viewed a far-reaching reform of Whitehall as essential, but once in office, the Attlee government merely tinkered. ${ }^{49}$ Henessey ascribes this not to timidity, but rather to self-confidence. Labour got its policies implemented with no suggestion that devious mandarins were thwarting reforming ministers. ${ }^{50}$ Once again, therefore, we see the link between constitutional policy and substantive policy, but this time militating in favour of retaining the constitutional status quo.

However, on another reading, the 1945 government can be seen as far more radical on constitutional issues. This reading is possible because identifying what is a constitutional change is a controversial matter: It is always possible to give the idea of a constitution a narrower or a wider meaning. ${ }^{51}$ If, as proposed earlier, we interpret constitutional reform as embracing all durable-though not necessarily permanent-alterations to the system of government, it might convincingly be argued that Labour's extension of public ownership

${ }^{46}$ See THORPE, supra note 35, at 125.

${ }^{47}$ See ATTLEE, supra note 31 , at 172.

${ }^{48}$ See PeARCE, supra note 37 , at 56.

${ }^{49}$ KeVin Theakston, The Labour Party and Whitehall 73 (1992).

${ }^{50} / d$. at 101.

${ }^{51}$ See BRUMMER, supra note 1 , at ch. 1. 
should itself be conceived as constitutional. As Tivey has contended, the idea behind the nationalization program was fundamentally political. The widening of the franchise had given working people the opportunity to dominate the political system, but to make this power effective, a means of economic power was required; otherwise ownership rights would obstruct the democratic power of the majority. While there was a practical case for doing something to revitalize ailing industries, it is doubtful that a non-socialist government would actually have nationalized them, since the driving impulse in favor of nationalization as a solution, and the form which nationalization took, were fundamentally ideological. ${ }^{52}$ Giving itself ownership of twenty percent of the economy meant that the government would be that much more effective in pursuing whatever economic goals it set for itself. Viewed in this light, it is easy to conceptualize nationalization as a constitutional issue. In the event, Labour's economic goals were modest. The party did not, for instance, use public ownership to promote a radical economic equality of outcome. Nationalization was, after all, piecemeal, and the government declined to maximize its transformative potential. ${ }^{53}$ The government did, however, operate a "planned economy" insofar as it brought about genuine nationwide growth through export-driven expansion. ${ }^{54}$ Indeed, unemployment never rose above three percent during the entire course of the government. $^{55}$

The progressive era ushered in by Labour swayed the Conservative Party towards the left. The Conservatives were no longer the party of unbridled capitalism, nor could they afford to be. The Party's traditional distinguishing feature-its commitment to the limited stategradually disappeared. ${ }^{56}$ Only in 1948, when the Conservatives filibustered the Gas Bill, did the Opposition offer much resistance to Labour's nationalizations. ${ }^{57}$ In the Party's Industrial Charter (1947), the Conservatives accepted the need for planning and adopted full employment as the overriding goal. ${ }^{58}$ Moreover the 1951-1964 Conservative

\footnotetext{
52 LeONARD TIVEY, Economic and Industrial Policy, in PARTY IDEOLOgY IN BRITAIN 132 (Leonard Tivey \& Anthony Wright eds., 1989).

53 See LAYBOURNE, supra note 40, at 120.

${ }^{54}$ MORgAN, supra note 30 .

${ }^{55}$ AUSTIN MitCHELL, ELECTION '45 119 (1995).

${ }^{56}$ Noel O'Sullivan, Conservatism, the New Right and the Limited State, in The Political SCIENCE OF British POLITICS (Jack Hayward \& Philip Norton eds., 1996).

${ }^{57}$ See PEARCE, supra note 37 , at 51, 54-6.

${ }^{58}$ Letwin argues that the Charter unequivocally committed the Tories to maintaining full employment and the welfare state, to lavish spending of public money, and generally to expanding the power of the State, which accepted nationalization as irreversible. She points out that it sold 2.5 million copies in six months. Harold Macmillan rejoiced that the 'progressive element in the party' had 'seized control... by the vigour of its intellectual and spiritual power.' SHIRLEY LetWIN, THE ANATOMY Of THATCHERISM 56 (1992).
} 
governments retained the welfare state, National Health Service, and all the public ownership of its predecessor except road transport. ${ }^{59}$

It is important to appreciate that the post-war "Butskellite" consensus to which the 1945 Labour government arguably gave birth ${ }^{60}$ was also a constitutional consensus. ${ }^{61}$ Both major parties supported parliamentary sovereignty, the first-past-the-post electoral system, and a powerful unitary government. Both parties saw the British system of government as basically satisfactory, albeit for somewhat different ideological reasons. Conservatives regarded the constitution as a Tory constitution enshrining strong governmental power, while Labour saw it as a collectivist constitution that allowed a class party to implement the politics of class solidarity. ${ }^{62}$

\section{E. The Thatcher-New Labour Period of Reaction}

Our final period differs from the first two in that the opinion among the governing elite shifted against egalitarianism. Thatcherism is said to have been inspired by the desire to stop Conservative governments from "getting into a political business which yielded no profits and only losses." ${ }^{63}$ Such was the perception within the party of the Heath government from 1970 to 1974. This disillusionment heralded an ideological and intellectual break from the past while the party was in opposition. Sir Keith Joseph emerged as a pivotal figure at this time. He published a compilation of speeches, Reversing the Trend, which argued for a total reversal of post-war Conservative policy. Joseph contended that a new liberal conservatism was required in order to promote human dignity so that people would not have their lives run by government. ${ }^{64} \mathrm{He}$ and party leader Margaret Thatcher established the Centre for Policy Studies that provided a pressure group for free market ideas. The Institute of Economic Affairs and the Adam Smith Institute also played a vital role in formulating policies for the party during the Conservatives' period in opposition. $^{65}$ Furthermore a younger generation of Conservative MPs had entered the House of Commons influenced by the writings of Hayek and Friedman. In 1976 the Party

\footnotetext{
${ }^{59}$ AlAn RYAN, Party Ideologies Since 1945, in UK Polttical PARTIES SINCE 1945 81-3 (Anthony Selden ed., 1990).

${ }^{60}$ Francis Beckett argues there was no real post-war consensus because of deep Conservative skepticism about the welfare state. See Francis BeCKETt, Clem ATtLeE 264 (1997).

${ }^{61}$ See Anthony Wright, The Constitution, in PARTY IDEOLOGY IN BRITAIN 187 (Leonard Tivey \& Anthony Wright eds., 1989).

${ }^{62}$ See id.

${ }^{63}$ Robert Skidelsky, Introduction, in THATCHERISM 1 (Robert Skidelsky ed., 1988).

${ }^{64}$ See Keith Joseph, The Humanity of Capitalism, THE TIMES, Jul. 28, 1986.

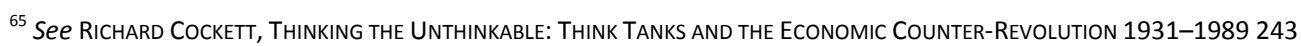
(1995).
} 
published The Right Approach, a policy document which demonstrated the onset of Thatcherite thinking on economic policy. The Right Approach was swiftly followed by a more hardline document, The Right Approach on the Economy, penned by Sir Geoffrey Howe, Sir Keith Joseph, James Prior, and David Howell, which emphasized the reduction in higher rates of income tax and the need to shift the taxation burden to indirect taxation, as well as the removal of obstacles to private enterprise. Strikingly, the Conservative Party did not pursue privatization at this stage. The Right Approach on the Economy merely proposed the (vague) long-term aim of replacing State ownership with wider ownership by the community or by the people. Indeed, denationalization played a fairly minor role throughout the first Thatcher administration. Then, between 1982 and 1987, the government privatized British Telecom, British Gas, and British Airways, with privatization of the water and electricity industries following in the wake of the Conservatives' 1987 victory. ${ }^{66}$ As in 1906, the political shift gathered pace during the course of a government.

Some commentators have found the philosophy of Thatcherism difficult to pin down. Letwin locates coherent philosophical underpinnings for Thatcherism in a distinctly British morality, which sees humans as completely rational, and reason being the facility which enables humans to interpret and respond to experience as they wish. She argues that this conception of the individual leads to the belief that there are no objective human needs, but rather desires and wants created by individuals themselves. This in turn justifies the market society and commercialization. ${ }^{67}$ An alternative view sees Thatcherism as internally contradictory, the rhetoric of freeing the individual from the state sitting unhappily with a strong centralization of power. ${ }^{68}$ The constitutional aim of Thatcherism, according to Bogdanor, was to topple the bastions of social democracy-trade unions, local government, National Health Service, and the professions. ${ }^{69}$ Such a stance did not accord with the Hayekian fondness for federalism, devolution, and the dispersing of political power. $^{70}$

In policy terms, the Conservative government's first priority was the control of inflation through a strict monetarist policy. This involved not only restricting the money supply, but also abandoning the goal of full employment. The early Thatcher years also saw a drastic regressive restructuring of taxation, through the doubling of indirect taxation (value added tax rose from eight percent to fifteen percent) and the lowering of income tax, particularly

\footnotetext{
${ }^{66}$ See Andrew Gamble, The free Economy and the Strong State: The Politics of Thatcherism 116 (1988).

${ }^{67}$ See LETWIN, supra note 58, at ch. 12.

${ }^{68}$ See Simon Jenkins, Thatcher And Sons: A ReVolution In Three Acts ch. 8 (2006).

${ }^{69}$ See Vernon Bogdanor, The Constitution, in THE THATCHER EFFECT 137 (Dennis Kavanagh \& Anthony Seldon eds., 1989).

${ }^{70}$ See FriedRICH HAYEK, THE CONSTITUTION OF LIBERTY 184-85 (1978).
} 
its upper rate. In 1979 the Conservative government removed currency exchange restrictions and scrapped credit controls and reserve requirements soon afterwards. Soaring unemployment obliged the government to scale back its desired public expenditure cuts, yet it still showed its zeal to squeeze spending wherever possible. Cabinet divisions over public expenditure were addressed by a reshuffle in favor of those who supported the Prime Minister's harder line. By the time of the second Thatcher government, recession had been replaced by mild recovery and the government prioritized controlling the expenditure of local government, denationalizing public-sector companies, and privatizing public services. Mrs. Thatcher's third term saw an emphasis on reforming the public services, with the introduction of internal markets, contracting-out, tendering, and financial incentives. ${ }^{71}$ By the end of her premiership, Britain surpassed its European neighbors not only in terms of privatization and deregulation, but also with regard to the reduction of trade union power. ${ }^{72}$

Just as during the progressive eras covered in this essay, so too under Thatcherism the opposition also modified its philosophy and policies to match those of the governing party. Any idea that the New Labour governments represented a sea-change away from Thatcherite approaches has been discredited by close analyses of New Labour policy. As Simon Jenkins puts it, "Thatcherism not only outlived Thatcher but was deepened and strengthened by her successors once she was gone." ${ }^{73}$ Her Conservative successor John Major, despite his less confrontational style, led a government which sold off the coal industry, introduced rail privatization, and tried (but failed) to sell off the Post Office. ${ }^{74}$ As for the opposition party, once in office, Jenkins shows that, far from reversing Thatcherism, New Labour supercharged it. ${ }^{75}$ As John Major has observed, Labour "left the Tory legacy largely undisturbed: Our trade union legislation remains in place ... not one of our many privatizations has been reversed ... it has even retained the tax cuts of the Tory years." ${ }^{76}$ In fact, the party's transformation predated Tony Blair's and Gordon Brown's premierships. Labour's embrace of private enterprise dated from the party's 1987 Policy Review, which can be seen as signaling Labour effectively ceasing to be a social democratic party, and its

\footnotetext{
${ }^{71}$ See Andrew Gamble, The Free Economy and the Strong State: The Politics of Thatcherism ch. 4 (1994).

${ }^{72}$ See Samuel Brittan, The Thatcher Government's Economic Power, in The Thatcher Effect: A DeCAde of Change 3 (Dennis Kavanagh \& Anthony Seldon, eds., 1989).

${ }^{73}$ Jenkins, supra note 68 , at 4 .

${ }^{74}$ See Anthony Seldon, Major: A Political Life 502-07 (1997).

${ }^{75}$ See JeNKINS, supra note 68, at 206.

${ }^{76}$ JOHN MAJOR, THE AUTOBIOGRAPHY 734 (1999).
} 
resurrection as a party of the newly-pervasive neoliberal economic orthodoxy. ${ }^{77}$ Tony Blair merely continued this trend by ruling out income tax increases, repealing the commitment to common ownership in Labour's constitution, and emphasizing an Anglo-American model of capitalism. ${ }^{78}$ Heffernan observes that the Blair government took up key objectives of the Thatcher and Major administrations: (1) Ensuring financial stability by promoting sound money and prioritizing low inflation; (2) placing the market at the center of economic life through deregulation and rejection of state intervention; (3) privatizing state-owned industries and utilities; and (4) disciplining the labor market through control of trade unions. ${ }^{79}$ As for Gordon Brown, who effectively determined much of domestic policy under Blair before replacing him, Jenkins offers the following assessment:

Brown never gave up on what can only be termed the unfinished business of Thatcher's first revolution, the disposal of public assets, the privatization of public services and the reform of social security in the direction of means-testing and workfare. His attachment to all these policies bordered on the messianic. $^{80}$

Neoliberal achievements of the New Labour governments included the widening of the gap between rich and poor, due largely to the refusal to shift taxation back from purchase to income taxes; ${ }^{81}$ the extensive use of the spend-now-pay-later Private Finance Initiative; and a general strongly-held preference for free-market and private sector solutions. ${ }^{82}$ Most calamitous in the medium term was the failure properly to regulate the banks and the financial sector. For good measure Blair positioned Labour as the only party which could reform the welfare state-in effect, as the "New Conservatives."

When it comes to constitutional change, the experience of both the Thatcher and the New Labour governments support the thesis of the essay. The constitutional reforms of the

\footnotetext{
77 See Colin Hay, The Political Economy of New Labour, in THE New LABOUR ReAder 59 (Andrew Chadwick \& Richard Heffernan eds., 2003). The Policy Review accepted that the privatizations of the Thatcher government ought not to be reversed. See Steven Fielding, The LABour PARTy 203 (2003).

${ }^{78}$ See Stephen Driver \& Luke Martell, NeW Labour: Politics After Thatcherism 40 (1998).

${ }^{79}$ See Richard Heffernan, New Labour and Thatcherism, in THE NEW LABOUR READER 49 (Andrew Chadwick \& Richard Heffernan, eds., 2003).

${ }^{80}$ JENKINS, supra note 68 , at 258.

${ }^{81}$ See Steven Fielding, The Labour Party: Continuity and Change in the Making of ‘NeW’ Labour 203 (2003).

${ }^{82}$ For example, by the end of New Labour's tenure eighty percent of care homes had been privatized.

${ }^{83}$ See Andrew RawnSley, Servants of the People: The Inside Story of NeW Labour 110 (2000).
} 
Thatcher era aimed to override post-war consensus, but on the face of it they seemed contradictory. On the one hand, the government deployed parliamentary sovereignty to centralize political power in the hands of government and to ward off judicial review. On the other hand, despite the Prime Minister's much-trumpeted support for parliamentary supremacy and national sovereignty, she approved the Single European Act (SEA), the first major revision of the European Community Treaty. The SEA very significantly reduced national autonomy for the benefit of the European single market. ${ }^{84}$ Such an erosion of sovereignty was made psychologically acceptable to Conservatives only by adhering to a formalistic analysis which posits a sharp divide between national constitutional law and international rules. $^{85}$ Inhabiting this fool's paradise, the Thatcher government could comfort itself that it was merely changing an international arrangement, not the British constitution. Only at a later stage could this unpleasant reality no longer be denied. ${ }^{86}$

Moreover the seeming paradox of relishing and undermining the power of Parliament at one and the same time is not contradictory if one starts from the assumption that the pursuit of substantive policy is given pride of place. As Gamble has suggested, "upholding Parliament came to mean trying to subordinate all institutions in civil society to the pursuit of the national goals approved by Parliament." ${ }^{87}$ The government wished to see off rivals to its policy-making preeminence, including domestic judicial review courts, local government, the trade unions, and the media. This would facilitate the implementation of neoliberal policy. But the government also wanted to secure the European single market. ${ }^{88}$ Contradictions on the level of constitutional principle were of little moment compared to the practical use of constitutional arrangements to achieve substantive policy ends.

For its part, New Labour's constitutional reforms also appear paradoxical. This is especially the case if we once again adopt a wider conception of "the constitutional" to include the constitutions of political parties. Because political parties are a well-established part of the political system, such a conceptual broadening is eminently defensible. ${ }^{89}$ But the Blair era inner-party constitutional reforms seemed curiously at odds with national ones. As Peter

\footnotetext{
${ }^{84}$ See BRUMMER, supra note 1 , at 88-90.

${ }^{85}$ See Margaret Thatcher, The Downing Street Years ch. 18 (1993).

${ }^{86}$ Turner comments that post-SEA there was a growing realization within the party that the single market was merely a prelude to further integrationist moves. Having sold membership to the public on the pragmatic basis that "Europe" was essentially an economic and trading organization, Mrs. Thatcher distanced herself from the Treaty she had signed. See JOHn TURNER, THE TORIES AND EUROPE 104-08 (2000).

${ }^{87}$ GAMBLE, supra note 71 , at 239.

${ }^{88}$ See TURNER, supra note 86 , at 557.

${ }^{89}$ It is after all the leader of the party best able to secure a Commons majority who becomes Prime Minister, and the rules of the party determine who becomes leader.
} 
Mair has observed, "at the institutional level, pluralism holds sway: Within the party itself, only one voice may be heard." ${ }^{100}$ Within the party itself, New Labour's leadership "imposed a Prussian discipline on their followers, exceeding anything attempted by any previous Labour government." ${ }^{91}$ The leadership completed a comprehensive transformation of the party structure that had commenced in $1983 .{ }^{92}$ At the heart of this transformation was centralization - an accumulation of power by the party leadership at the expense of both the party's National Executive Committee and its constituency parties. ${ }^{93}$ Meg Russell observes that, while there was never a golden age of democracy when the Labour Party was controlled by its members, nonetheless in many ways members had been disempowered by the changes since the early 1980s, in particular as regards their ability to exercise "voice." ${ }^{94}$ Yet at the same time, outside the party, New Labour pursued a somewhat pluralistic program of constitutional reform. ${ }^{95}$ One should not over-exaggerate this program, New Labour still preferred to accommodate reforms within a Westminster model which preserved executive dominance. ${ }^{96}$ Nonetheless a modest element of checks and balances was introduced. Yet it seems strange that what was given with one hand by way of new checks and balances should be taken away with the other through top-down control of inner party life. ${ }^{97}$ Mair argues that there is, however, a common theme: To take party of the equation. Previously, he contends, "British democracy was party democracy, and party democracy gained its purchase through parliamentary sovereignty." ${ }^{98}$ Britain has traditionally had a particularly majoritarian constitution. ${ }^{99}$ But New Labour shifted the constitution away from partisan democracy towards a more consensual model, through devolution, abandonment of first-past-the-post voting for regional assembly and European elections, the independence of the Bank of England, the Human Rights Act 1998, elected mayors, and a more legitimate House of Lords. Both internal and external changes aimed

\footnotetext{
${ }^{90}$ Peter Mair, Partyless Democracy, 2 New Left ReV. 21 (2000).

${ }^{91} / d$.

92 See Thomas Quinn, Modernising the Labour Party: Organisational Change Since 1983191 (2004). In any event, the "Prussian discipline" ultimately backfired, with backbench MPs becoming somewhat more independent. See PHILIP COWLEY, THE REBELS (2005).

${ }^{93}$ See ERIC Shaw, The Labour Party Since 1945202 (1994).

${ }^{94}$ See Meg Russell, Building New Labour: The Politics of Party Organisation 282-83 (2005).

${ }^{95}$ See David Marquand, Progressive or Populist? The Blair Paradox, in The Progressive Dilemma: From Lloyd George TO BLAIR 225-46 (David Marquand ed., 1999).

${ }^{96}$ Steve Ludlam \& Martin SMith, Governing as New Labour: Policy and Politics Under Blair 126 (2004).

${ }^{97}$ See Mair, supra note 90, at 26.

${ }^{98}$ Id. at 27.

${ }^{99}$ See Arend Lijphart, Democracies: Patterns of Majoritarian and Consensus Government in TWenty-One Countries (1984).
} 
to neuter political parties. ${ }^{100}$ Mair's thesis becomes compelling when one considers the substantive policies which New Labour was determined to see through. While it was repelled by the individualistic message of Thatcherism, New Labour nonetheless opposed any return to pre-Thatcher policies. It was committed instead to free trade, flexible labor markets, sound money, and entrepreneurial capitalism. ${ }^{101}$ Hayek had advocated checks and balances in the external constitution in order to secure these policies in the long term, and it seems that New Labour was, to a certain extent, influenced by such thinking. ${ }^{102}$ But change was also required in the internal party constitution. In the late 1970s and early 1980s the Labour Party rank and file secured several reforms designed to oblige the Party's leadership to implement the policies agreed upon by Labour's annual conference. ${ }^{103}$ Shocked by these changes, the party establishment set out to comprehensively centralize power in its own hands. ${ }^{104}$ By the time of the Blair-Brown premierships, both the party rule book and the party membership had changed quite dramatically. The Labour rank and file largely accepted neoliberal policies, but were not always willing to embrace them in the full-blooded form favored by the New Labour leadership. For example, Labour's annual conference demanded such policies as renationalization of the railways and a less aggressive approach to welfare reform. Having, however, transformed the party rule book in the government's favor, ministers felt able to immediately veto any policy change not to their liking. Thus, yet again, constitutional change was linked to the untrammeled achievement of substantive policy.

\section{F. Conclusion: The Legitimacy of Political Herding}

As night follows day, humans will herd together in support of the political spirit of the age as different philosophies of life become in turn fashionable and unfashionable. It might be argued, however, that empirical reality is not complemented by normative desirability. Just as we deride the financial herding in favor of subprime mortgages, dotcom companies, the South Sea Bubble, and tulip mania, so too it might be contended that political herding does not deserve to be encouraged.

Yet one can differentiate normatively between political and financial herding. Different readers will quite naturally take differing views on the merits and demerits of the

\footnotetext{
100 See Danny Nicol, Professor Tomkins' House of Mavericks, 2006 PuB. L. 467. Cf. Adam Tomkins, Professor Tomkins' House of Mavericks: A Reply, 2007 PUB. L. 33.

${ }^{101}$ See DRIVER \& MARTELL, supra note 78 , at 2-3.

102 See Friedrich HAYEK, LAW, LegISLATION AND LIBERTY ch. 18 (1982).

${ }^{103}$ See generally David Kogan \& MaURice Kogan, THE BATtLE FOR THE LABOUR PARTY (1982).

${ }^{104}$ The Labour leadership of the 1980s and 1990s did not share the respect of the Attlee generation for the Party's internal structures and delegate democracy, which was itself a reaction against the experiences of MacDonaldism. See LEWIS MinkIN, The LABOUR PARTY CONFERENCE 277 (1980).
} 
progressive eras and the period of reaction covered in this essay. There may also be a legitimate objection that political herding blots out the consideration of alternative views and suppresses plurality. Yet what cannot be denied is that progressive eras and periods of reaction represent supreme acts of political experimentation. Successive generations of human beings produce different ideas of how "the good life" should be lived. In a human society in which "there are many of us, and we disagree about justice," the ability to change society in response to changing ideas deserves to be carefully preserved. ${ }^{105}$ The alternative would be to preserve indefinitely the social and economic status quo of a bygone age even after it has become discredited. The veering of the political community from right to left and from left to right supports J.A.G. Griffith's observation in The Political Constitution that "society is endemically in a state of conflict between warring interest groups, having no consensus or unifying principles sufficiently precise to be the basis of a theory of legislation." ${ }^{106}$ The British constitution ought to accommodate this state of conflict. It should not act as a strait-jacket by stifling political experimentation in any particular epoch.

Such experimentation will inevitably include a constitutional dimension. This essay has attempted to show that the politics of constitutional reform are inextricably linked to the politics of substantive policy and overarching ideology. Keith Ewing has observed that "constitutional law does not stand above politics: They are two sides of one coin," and that "social, economic and political change will, in turn, lead to constitutional change to accommodate or reflect new social, economic, and political relations." ${ }^{107}$ Thus a progressive era or a period of reaction will often generate considerable constitutional change. Danger comes only where constitutional reform is such as to prevent future shifting between periods of reaction and progressive eras. In order to retain constitutional legitimacy, therefore, on the one hand, the constitution needs to permit the political experimentation of progressive eras and periods of reaction, including constitutional experimentation. But on the other hand, the constitutional changes devised in one period ought not to unduly impede a change of political direction at a future point in time.

In this regard supranational obligations provide particular cause for concern, being more difficult to modify under conditions of globalization than domestic arrangements. Increasingly, choices between economic policies have been internationalized, and the trend towards effective enforcement through the creation of supranational institutions has been strengthened. ${ }^{108}$ The avowed intention has been to compel countries to stick to certain policies irrespective of the outcomes of democratic elections, and this has

\footnotetext{
${ }^{105}$ See JeREMY WALDRON, LAW AND DiSAGREEMENT 1 (1999).

${ }^{106}$ John Griffith, The Political Constitution, 42 MoD. L. REV. 1, 19 (1979).

${ }^{107}$ Keith Ewing, The Politics of the British Constitution, 2000 PUB. L. 405, 436.

${ }^{108}$ See NicOL, supra note 2 , at ch. 1.
} 
succeeded, certainly in the context of the European single market. The pro-private sector orientation of that market is becoming increasingly apparent, exemplified by the recognition that the Health and Social Care Act 2012 may make privatization within the NHS irreversible, by dint of European Union competition law. The present bias of the single market could only be overturned if all EU Member States agreed to amend the Treaty on the Functioning of the European Union to that effect. The tension between this rigidity and the traditional flexibility of the British system of government reflects the ongoing tension between two different constitutional cultures-the legal constitution and the political constitution-and their respective claims to the proprietorship of the constitution. ${ }^{109}$

Yet a political community ought not to be precluded from releasing itself from the "common sense" of an earlier era. After all, the common sense of today will not necessarily be the common sense of tomorrow. It is here that the rule against self-bindingness in the British constitution comes to the fore. As Ewing again observes, there are some enduring constitutional values which make certain forms of change difficult to accomplish. ${ }^{110}$ Most particularly, the doctrine of parliamentary sovereignty famously ordains that the United Kingdom Parliament cannot be bound by its predecessors nor can it bind its successors. This rule has particular resonance set against the backdrop of our history of progressive eras and periods of reaction, yet its underlying justification is in tension with Britain's supranational obligations. This endangers democracy by stopping the politics of the country swinging from left to right or from right to left, in conformity with dominant opinion.

The narratives set out in this essay show that "constitutional herding" is part and parcel of political herding. Just as political herding is fallible, so too is herding in support of constitutional change. For this reason flattering talk of constitution drafters engaging in "solemn deliberation" ought to be taken with a large grain of salt. It is indeed unduly flattering to portray a period of constitution-mongering as a moment of great constitutional wisdom when it is more normally part of the rough-and-tumble politics driven by an ideological group imperative. Recent experience underscores the lack of sober dwelling on implications before constitutional reform is enacted. There is little hard evidence that the political behavior governing constitutional change is more carefully considered than political behavior governing ordinary legislation, and in any case there isas we have seen in his essay-a blurred line between what is and what is not constitutional.

This essay has counselled against a depoliticized portrayal of constitutional change. It has shown that constitutional change usually forms an inseparable part of the substantive

\footnotetext{
109 See Michael foley, The Politics of the British Constitution 286 (1999). See also Danny Nicol, The Legal Constitution: United Kingdom Parliament and European Court of Justice, 5 J. LEGIS. STUD. 135 (1999).

${ }^{110}$ See Ewing, supra note 107, at 405, 436.
} 
program of a progressive era or period of reaction, a program to which a political community inhabiting a different era may not subscribe. This serves to underline that it is imperative to be able to change-and re-change-the constitution without undue difficulty. 